\title{
PENGARUH PENYALURAN KREDIT TERHADAP SISA HASIL USAHA PADA KOPERASI SIMPAN PINJAM SEJAHTERA KOTA BAUBAU
}

\author{
Azaluddin \\ Program Studi Akuntansi, Fakultas Ekonomi \\ Universitas Muhammadiyah Buton No. 36 Baubau \\ E-mail:aza-hra75@yahoo.co.id
}

\begin{abstract}
Abstrak
Tujuan penelitian ini untuk mengetahui pengaruh penyaluran SHU pada koperasi Simpan Pinjam Sejahtera Kota Baubau. Penelitian ini dilakukan pada Koperasi Simpan Pinjam Sejahtera Kota Baubau yang beralamat di jalan Martadinata Nomor 1B Kelurahan Batulo, Kota Baubau, Sulawesi Tenggara. Populasi penelitian ini adalah jumlah penyaluran kredit dan sisa hasil usaha pada Koperasi Simpan Pinjam Sejahtera Kota Baubau selama 3 tahun, yaitu dari tahun 2011 sampai dengan tahun 2013. Hasil penelitian ini menunjukan penyaluran kredit pada Koperasi Simpan Pinjam Sejahterah Kota Baubau selalu meningkat, tetapi perkembangan peningkatannya dari tahun ke tahun cenderung Menurun. Hal ini di akibatkan karena adanya anggota yang keluar karena pindah kerja, pensiun, atau berhenti atas kehendaknya sendiri dan disebabkan pula oleh bertambah serta berkurangnya setoran simpanan wajib dan simpanan pokok dari para anggota, bertambah atau berkurangnya dana cadangan yang ada pada koperasi; Sisa hasil usaha pada Koperasi Simpan Pinjam Sejahterah Kota Baubau dari tahun 2011 sampai dengan tahun 2013 juga cenderung fluktuatif. Hal ini di sebabkan oleh semakin besarnya modal sendiri yang mampu dihimpun oleh koperasi, bertambah atau berkurangnya pendapatan yang di peroleh baik dari bunga pinjaman dan deviden atas jasa simpan pinjam dan investasi yang di lakukan oleh koperasi, serta bertambah atau berkurangnya biaya-biaya yang di keluarkan dari unit-unit usaha pada koperasi.
\end{abstract}

Kata kunci: SHU, koperasi sejahtera.

\begin{abstract}
The purpose of this study to determine the effect on the distribution SHU Sejahtera Savings and Loans Cooperative Baubau City. Research was conducted on Credit Unions Sejahtera Baubau City address at the Village Batulo Martadinata No. 1B, City of Baubau, Southeast Sulawesi. The population of this study is the number of lending and operating results on Credit Unions Prosperous Baubau City for 3 years, ie from 2011 to 2013. The results of this study showed lending in Credit Unions Sejahterah Baubau always increasing, but the development of improvement from year to year tend Descending. It is in the causes for their members out for a new job, retirement, or quit on his own and is also caused by the increase and decrease in mandatory savings deposits and principal savings of members, increasing or decreasing the reserve funds exist in cooperatives; Of net income at Credit Unions Sejahterah Baubau City from 2011 to 2013 also tend to fluctuate. This is caused by the growing amount of capital itself is capable collected by cooperatives, increase or reduction in income that was obtained either from interest on loans and paid on the services of savings and investments undertaken by cooperatives, as well as the increase or decrease in costs is issued of the business units in the cooperative.
\end{abstract}

Keywords: SHU, prosperous cooperatives. 


\section{SANG PENCERAH}

Volume 2, Nomor 1, Februari 2016, Hlm. 17-22

Azaluddin: Pengaruh Penyaluran Kredit Terhadap Sisa ...

\section{Pendahuluan}

Perekonomian merupakan salah satu tolok ukur dari kemakmuran. Perekonomian yang stabil dan meningkat dapat membuktikan bahwa seseorang atau suatu organisasi baik itu perusahaan ataupun negara telah mengalami keberhasilan. Koperasi merupakan salah satu lembaga non keuangan dimana keberadaannya cukup dekat dan dikenal masyarakat. Peranan koperasi di masyarakat sangat besar bukan hanya dalam hal pemberi bantuan modal saja, namun koperasi juga memberikan pembinaan dan bantuan pemasaran produk anggotanya. Koperasi dinilai sebagai lembaga ekonomi yang sangat cocok jika dikembangkan di masyarakat Indonesia. Asas koperasi yang kekeluargaan serta dengan semangat kegotong-royongan membuat lembaga koperasi dapat diterima masyarakat.

Koperasi pada umumnya terbentuk dalam rangka menyejahterakan anggota dan dapat menghasilkan kerjasama yang harmonis sesama pelaku ekonomi karena memberikan kesempatan kepada anggotaanggotanya untuk memperoleh pinjaman dengan mudah dan dengan bunga yang ringan. Dalam hal ini, koperasi menyalurkan kredit/pinjaman dana kepada para anggota yang membutuhkan. Salah satu koperasi yang melakukan kegiatan penyaluran kredit di Kota Baubau adalah Koperasi Simpan Pinjam Sejahtera. Kegiatan koperasi tersebut bergerak dalam lapangan usaha pembentukan modal melalui tabungantabungan para anggota secara teratur dan terus menerus untuk kemudian disalurkan kembali kepada para anggota yang membutuhkan modal.

Kegiatan penyaluran kredit ini, menarik perhatian masyarakat Kota Baubau karena memberikan kesempatan bagi mereka untuk memperoleh pinjaman dengan mudah dengan bunga yang ringan. Dari pinjaman yang diperoleh tersebut mereka bisa menggunakannya sebagai modal usaha atau modal lainnya.

Pada kenyataannya kondisi ekonomi masyarakat Kota Baubau tidak selalu baik bahkan cenderung naik turun. Pada saat kondisi ekonomi sedang turun, Koperasi Simpan Pinjam (KSP) Sejahtera memberikan jasa penyaluran kredit kepada anggota yang membutuhkan dana. Semakin banyak kredit yang disalurkan, maka semakin banyak pendapatan bunga yang diperoleh. Sehingga pendapatan koperasi meningkat, yang akhirnya juga memengaruhi Sisa Hasil Usaha (SHU) yang diperoleh Koperasi. Berdasarkan uraian di atas, fokus penelitian ini adalah bagaimana pengaruh penyaluran SHU pada koperasi Simpan Pinjam Sejahtera Kota Baubau.

Tujuan penelitian ini untuk mengetahui pengaruh penyaluran SHU pada koperasi Simpan Pinjam Sejahtera Kota Baubau.

\section{Metode Penelitian}

\section{Lokasi Penelitian}

Penelitian ini dilakukan pada Koperasi Simpan Pinjam Sejahtera Kota Baubau yang beralamat di jalan Martadinata Nomor 1B Kelurahan Batulo, Kota Baubau, Sulawesi Tenggara.

\section{Populasi dan Sampel}

Definisi Menurut Sekaran (2009:121) Populasi adalah keseluruhan kelompok orang, kejadian, atau hal minat yang ingin peneliri investigasi. Adapun yang menjadi populasi dalam peneliti adalah Koperasi Simpan Pinjam Sejahtera Kota Baubau. Sampel adalah sebagain dari populasi. Populasi ini yang terdiri adalah jumlah penyaluran kredit dan sisa hasil usaha pada Koperasi Simpan Pinjam Sejahtera Kota Baubau selama 3 tahun, yaitu dari tahun 2011 sampai dengan tahun 2013. 


\section{SANG PENCERAH}

Volume 2, Nomor 1, Februari 2016, Hlm. 17-22

Azaluddin: Pengaruh Penyaluran Kredit Terhadap Sisa ...

\section{Jenis dan Sumber Data}

Adapun jenis data yang digunakan dalam penelitian ini adalah data kuantitatif berupa data perkembangan jumlah penyaluran kredit dan data sisa hasil usaha Koperasi Simpan Pinjam Sejahtera Kota Baubau selama 3 tahun, yaitu dari tahun 2011 sampai dengan tahun 2013. Sumber data yang digunakan dalam penelitian ini adalah data primer yaitu data yang diperoleh dari KSP Sejahtera Baubau berupa informasi dari manajer koperasi, kepala bagian dan beberapa pengurus serta beberapa anggota koperasi yang dianggap representative; Data sekunder yaitu data yang diperoleh dari arsip koperasi sejahtera, literature-literatur ataupun perpustakaan dan skripsi terdahulu yang relevan dengan penelitian ini.

\section{Teknik Pengumpulan Data}

Teknik pengumpulan data dalam penelitian ini sebagai berikut.

1. Wawancara yaitu pengumpulan data dengan jalan mengadakan wawancara atau tanya jawab secara lisan dengan pengurus koperasi mengenai penyaluran kredit dan sisa hasil usaha pada Koperasi Simpan Pinjam Sejahtera Kota Baubau.

2. Dokumentasi yaitu pengambilan data yang didokumentasikan atau arsip oleh Koperasi Simpan Pinjam Sejahtera Kota Baubau.

3. Studi pustaka merupakan pengumpulan data yang bersumber pada literatur yang diperoleh dari perpustakaan yang berkaitan dengan penelitian ini.

\section{Metode Analisis Data}

Analisis data penelitian ini, menggunakan metode analisis regresi linear sederhana. Sebuah variabel terikat dihubungan dengan variable terikat bebas maka persamaan regresi linear sederhananya sebagai berikut:

$$
\mathrm{Y}=\mathrm{a}+\mathrm{bX}
$$

Keterangan:

$\mathrm{Y}=$ Sisa hasil usaha

$\mathrm{X}=$ Penyaluran Kredit

$\mathrm{a}=$ Konstanta

$b=$ Koefisiensi Regresi

\section{Pembahasan}

Berdasarkan hasil peneilitan yang diperoleh informasi yang didapatkan bahwa untuk mendapatkan kredit sisa hasil yang yang diperoleh adalah dengan cara:

a. Umum

Kegiataan kas pada tahun yang lalu menangkut kas penerimaan dan pengeluaran kas, banyak yang mengendap (tidak produktif) dalam melakukan pembayaran kredit sehingga menyebabkan pinjaman kredit semakin berkurang. Kas yang ideal tidak mendukung kegiatan operasional rutinitas setiap bulan tidak maksimal tiap bulan.

\section{b. Pelaksanaan Kredit}

Modal koperasi terdiri dari modal sendiri, modal pinjaman, dan modal jangka panjang. Pada koperasi sejaterah ini hanya tergampar dua komponen yaitu modal sendiri (terdiri dari simpanan pokok, simpanan wajib, simpanan wajib, hibah cadangan saham, deviden) dan modal pinjaman (hutang lancar).

\section{c. Hasil Sistem dan Prosedur Pembaruan Pinjaman}

Banyaknya tunggakan cicilan dan jasa dalam tahun 2013, maka kebijakan dalam pemberian kredit tahun 2013 adalah sebagai berikut:

1. Bagi anggota yang sudah menganggsur pinjaman minimal 75\% jika ingin memperbaruhi pinjamannya diharuskan membayar jasa tunai pinjaman 1 bulan, tunai.

2. Bagi anggota yang sudah mengasnggsur antara 50\% s.d. $74 \%$, 


\section{SANG PENCERAH}

Volume 2, Nomor 1, Februari 2016, Hlm. 17-22

Azaluddin: Pengaruh Penyaluran Kredit Terhadap Sisa ...

jika ingin memperbaruinya pinjaman diharuskan membayar jasa tunai sebesar 2 bulan jasa, tunai.

3. Jika anggota ang baru menganggsur sebesar $25 \%$ s.d. $49 \%$ maka yang bersangkutan harus membayar jasa pinjaman secara tunai 4 bulan, tunai.

\section{d. Kesimpulan dan Usul Kredit di Usaha Simpan Pinjam}

Apabila anggota ideal memenuhi kewajibannya jatuh tempoh sesuai dengan akad kreditnya, maka yang bersangkutan disurati, bila dalam 6 (enam) bulan kedepan setelah batas waktu akan datang bersangkutan dibekukan (macet) dan diserahkan kepada kuasa pengacara Negara dalam hal ini kejaksaan untuk menagih kepada yang bersangkutan sebesar wajib pokok dan jasa serta denda yang tertunggak. Perhatikan tabel berikut.

Tabel 1. Jumlah Pendapatan Koperasi dan Sisa Hasil usaha Tahun 20112013

\begin{tabular}{|c|c|c|c|}
\hline \multirow{2}{*}{ URAIAN } & \multicolumn{3}{|c|}{ PENDAPATAN } \\
\hline & $2011(\mathrm{Rp})$ & $2012(\mathrm{Rp})$ & $2013(\mathrm{Rp})$ \\
\hline $\begin{array}{l}\text { Pendapatan Jasa Simpan } \\
\text { Pinjam }\end{array}$ & $759,541,450$ & $677,303,855$ & $694,341,041$ \\
\hline Pendapatan Saksi & $42,282,175$ & $40,510,515$ & $40,691,626$ \\
\hline Pendapatan Propisi & $30,330,000$ & $29,805,000$ & $35,130,000$ \\
\hline Pendapatan Jasa Bank & $4,040,140$ & $9,368,359$ & $4,200,000$ \\
\hline Pendapatan di luar Usaha & $8,848,740$ & $19,729,359$ & $20,000,000$ \\
\hline Pendapatan Asuransi & $18,508,385$ & $19,412,240$ & $18,316,612$ \\
\hline Selisih Kas & & 600 & 30,000 \\
\hline \multirow[t]{2}{*}{ Total Pendapatan } & $863,550,890$ & $796,129,928$ & $812,709,279$ \\
\hline & \multicolumn{3}{|c|}{ TAHUN } \\
\hline BIAYA-BAIYA & 2011 & 2012 & 2013 \\
\hline Biaya Atk & $7,360,200$ & $7,633,500$ & $8,884,150$ \\
\hline Biaya Komunikasi & $1,698,000$ & $1,358,100$ & $1,045,500$ \\
\hline Transportasi Karyawan & $11,832,600$ & $11,832,600$ & $11,832,600$ \\
\hline Tunjangan Beras Karyawan & $18,947,400$ & $18,947,400$ & $18,947,900$ \\
\hline Gaji Karyawan & $207,004,000$ & $207,006,400$ & $219,438,500$ \\
\hline Perj. Dinas Pengelolah & $1,800,000$ & - & $1,255,000$ \\
\hline $\begin{array}{l}\text { By. Pemeliharaan Kes. } \\
\text { Pengelolah }\end{array}$ & $18,495,600$ & $18,495,600$ & $18,495,600$ \\
\hline
\end{tabular}

\begin{tabular}{|c|c|c|c|}
\hline Perangsang Unit & $10,485,400$ & $9,071,400$ & $6,808,300$ \\
\hline Biaya Transportasi & & & \\
\hline Antarsurat & $1,101,600$ & $1,105,500$ & $1,228,000$ \\
\hline Biaya Listrik dan Air & $2,710,000$ & $2,647,300$ & $3,049,500$ \\
\hline Jasa SIMTARA & $14,485,100$ & $12,022,000$ & $13,878,000$ \\
\hline $\begin{array}{l}\text { By. TIM penanggu. Angg. } \\
\text { Beku }\end{array}$ & 548,000 & $4,840,100$ & $22,330,420$ \\
\hline $\begin{array}{l}\text { By. TAG. Tunggakan Jasa } \\
\text { Pajak Perusahaan Tahun }\end{array}$ & $48,680,680$ & $20,503,600$ & $5,041,400$ \\
\hline Berjalan & $21,826,884$ & $14,032,500$ & $12,813,750$ \\
\hline Pajak Tahun Lalu & 210,000 & - & - \\
\hline Biaya Pajak Bank & 808,025 & - & - \\
\hline Biaya Adm Bank & 342,777 & $2,113,666$ & $1,092,400$ \\
\hline Iuran JAMSOSTEK & $15,652,280$ & $15,908,604$ & $16,252,995$ \\
\hline Biaya Penyusutan & & & \\
\hline Bangunan & $4,000,000$ & $4,000,000$ & $1,118,849$ \\
\hline Biaya Penyusutan Investasi & $12,700,000$ & $12,700,000$ & $1,475,000$ \\
\hline Honor Pengurus & $78,846,000$ & $78,846,000$ & $78,846,000$ \\
\hline Honor Pengawas & $29,280,000$ & $29,280,000$ & $29,280,000$ \\
\hline Biaya RAT & $34,195,000$ & $35,000,000$ & $33,210,000$ \\
\hline $\begin{array}{l}\text { BY. Rapat Pengurus \& } \\
\text { Pengawas }\end{array}$ & - & 840,000 & $2,580,000$ \\
\hline Biaya Lembur & - & $1,800,000$ & - \\
\hline Sumbangan-sumbangan & 650,000 & 600,000 & 500,000 \\
\hline Biaya Tamu & 50,000 & - & \\
\hline $\begin{array}{l}\text { Pakaian Kesejahteraan } \\
\text { Anggota }\end{array}$ & $150,000,000$ & $137,500,000$ & $105,000,000$ \\
\hline $\begin{array}{l}\text { THR karyawan } \\
\text { Pakaian Seragam }\end{array}$ & $20,714,700$ & $20,714,100$ & $21,749,911$ \\
\hline Karyawan & $3,900,000$ & $3,900,000$ & $3,900,000$ \\
\hline THR Pengurus & $7,816,000$ & $7,816,000$ & $7,816,000$ \\
\hline THR Pengawas & $3,157,300$ & $3,157,300$ & $3,157,300$ \\
\hline BiayaTak Terduga & $4,250,000$ & $3,280,000$ & 550,000 \\
\hline Pakaian Seragam Pengurus & $2,000,000$ & $2,000,000$ & $2,000,000$ \\
\hline $\begin{array}{l}\text { Biaya Pemeliharaan } \\
\text { Gedung/Ins }\end{array}$ & $1,181,500$ & $5,014,500$ & $1,090,000$ \\
\hline $\begin{array}{l}\text { BY. Pengh. Piutang Ragu- } \\
\text { ragu }\end{array}$ & $10,000,000$ & $10,000,000$ & $10,000,000$ \\
\hline PBB dan Retribusi & 473,190 & 470,200 & 524,000 \\
\hline Eksploitasi Roda Dua & 40,000 & - & \\
\hline Tunjangan Beras Pengurus & $5,700,000$ & $5,700,000$ & $5,700,000$ \\
\hline Transport Pengurus & $4,200,000$ & $4,200,000$ & $4,200,000$ \\
\hline T.Transpor Pengawas & $3,420,000$ & $3,420,000$ & $3,420,000$ \\
\hline T.Beras Pengawas & $2,520,000$ & $2,520,000$ & $2,520,000$ \\
\hline Honor 13 Pengurus & $7,816,000$ & $7,816,000$ & $7,816,000$ \\
\hline Honor 13 Pengawas & $3,157,300$ & $3,157,300$ & $3,157,300$ \\
\hline Gaji 13 Karyawan & $20,714,700$ & $20,714,700$ & $21,749,805$ \\
\hline Pak. Seragam Pengawas & 900,000 & 900,000 & 900,000 \\
\hline Penyegar Harian/SNAK & $2,400,000$ & $2,400,000$ & $2,400,000$ \\
\hline Pesangon Pengawas & - & $9,471,900$ & $35,972,000$ \\
\hline
\end{tabular}




\section{SANG PENCERAH}

Volume 2, Nomor 1, Februari 2016, Hlm. 17-22

Azaluddin: Pengaruh Penyaluran Kredit Terhadap Sisa ...

\begin{tabular}{lrrr}
\hline Total Biaya & $798,070,236$ & $764,736,270$ & $753,026,180$ \\
\hline SHU & $65,480,654$ & $31,393,658$ & $59,683,099$ \\
\hline
\end{tabular}

Tabel 2. Penerima Kredit dari Tahun 2011 s.d. 2013

\begin{tabular}{lccc}
\hline \multirow{2}{*}{ KSP } & \multicolumn{3}{c}{ JUMLAH ANGGOTA } \\
\cline { 2 - 4 } & $\mathbf{2 0 1 1}$ & $\mathbf{2 0 1 2}$ & $\mathbf{2 0 1 3}$ \\
\hline Induk & 1,144 & 1,133 & 1,122 \\
Dana Konvensional & 154 & $\mathbf{1 5 2}$ & $\mathbf{1 5 0}$ \\
Kemitraan & 9 & 9 & 9 \\
\hline Jumlah & $\mathbf{1 , 3 0 7}$ & $\mathbf{1 , 2 9 4}$ & $\mathbf{1 , 2 8 1}$ \\
\hline
\end{tabular}

Tabel 3. Perkembangan Usaha Simpan Pinjam KSP SEJAHTERAH Kota Baubau

\begin{tabular}{lcccccc}
\hline Tahun & \multicolumn{2}{c}{2011} & \multicolumn{2}{c}{2012} & \multicolumn{2}{c}{2013} \\
\hline \multicolumn{1}{c}{ Bulan } & $\begin{array}{c}\text { Pemberian } \\
\text { Pinjaman }\end{array}$ & SHU & $\begin{array}{c}\text { Pemberian } \\
\text { Pinjaman }\end{array}$ & SHU & $\begin{array}{c}\text { Pemberian } \\
\text { Pinjaman }\end{array}$ & SHU \\
\hline Januari & $213,000,000$ & $14,333,900$ & $204,000,000$ & $12,094,183$ & $205,800,000$ & $14,333,900$ \\
Februari & $287,000,000$ & $20,190,196$ & $347,600,000$ & $25,113,433$ & $287,000,000$ & $20,190,196$ \\
Maret & $302,500,000$ & $29,467,446$ & $302,000,000$ & $24,133,999$ & $322,000,000$ & $24,133,999$ \\
April & $263,500,000$ & $(14,154,056)$ & $306,000,000$ & $(27,339,301)$ & $306,600,000$ & $(14,154,056)$ \\
Mei & $431,500,000$ & $(1,290,003)$ & $147,000,000$ & $(18,790,251)$ & $431,500,000$ & $(18,790,251)$ \\
Juni & $244,500,000$ & $(25,325,716)$ & $242,500,000$ & $(48,117,402)$ & $242,500,000$ & $(25,325,716)$ \\
Juli & $270,500,000$ & $(10,332,416)$ & $258,000,000$ & $(39,151,277)$ & $276,500,000$ & $(39,151,277)$ \\
Agustus & $268,000,000$ & $(26,466,918)$ & $279,000,000$ & $(71,736,207)$ & $279,000,000$ & $(26,466,918)$ \\
September & $233,500,000$ & $3,369,551$ & $350,000,000$ & $(66,050,708)$ & $344,410,000$ & $(66,050,708)$ \\
Oktober & $379,500,000$ & $12,744,334$ & $252,000,000$ & $(59,006,588)$ & $250,700,000$ & $12,744,334$ \\
November & $273,500,000$ & $35,943,662$ & $313,000,000$ & $(51,522,483)$ & $214,600,000$ & $(51,522,483)$ \\
Desember & $211,900,000$ & $65,460,654$ & $256,965,000$ & $31,394,258$ & $200,260,000$ & $59,723,109$ \\
\hline Jumlah & $3,378,900,000$ & $65,460,654$ & $3,258,065,000$ & $31,394,258$ & $3,360,870,000$ & $59,723,109$ \\
\hline
\end{tabular}

\section{Analisis Regresi Linear Sederhana}

$\begin{array}{lr}\sum X= & 9,992,370,000 \\ \sum y= & 156,598,021 \\ \sum x 2= & 19,987,740,000 \\ \sum Y 2= & 1,313,196,042 \\ \sum x y= & 524,087,150,716,230,000\end{array}$

Keterangan:

$\mathrm{Y}=\mathrm{a}+\mathrm{b} \mathrm{X}$

$\mathrm{Y}=\mathrm{SHU}$

$\mathrm{a}=$ Nilai Konstanta

$$
\begin{aligned}
& b=\text { Koefisien Arah Regresi } \\
& X=\text { Modal Sendiri }
\end{aligned}
$$

Untuk Menghitung a mengunakan Rumus Sebagai berikut :

$$
\begin{aligned}
& a= \frac{\left(\sum y\right)\left(\sum x 2\right)-\left(\sum X\right)\left(\sum x y\right)}{N\left(\sum x 2\right)-\left(\sum X\right) 2} \\
& a=\quad \begin{array}{l}
(156,598,021) \quad(19,984,740,000) \\
\end{array} \frac{(9,992,370,000)(524,087,150,716,230,000)}{3(19,984,740,000)-(9,992,370,000)} \\
& a=\frac{(5,236,872,719,072,760,000,000,000,000.00)}{59,954,220,000} \\
& a=-8,734,790,000,000,000,000
\end{aligned}
$$

Untuk Menghitung $\mathrm{b}$ mengunakan rumus sebagai berikut:

$$
\begin{aligned}
& \mathrm{b}= \mathrm{n} \underset{\mathrm{n}\left(\sum \mathrm{xy}\right)-\left(\sum \mathrm{X}\right)-\left(\sum \mathrm{X}\right) 2}{\left(\sum \mathrm{y}\right)} \\
& \mathrm{b}= \quad \begin{array}{l}
3 \quad(524,087,150,716,230,000) \\
\end{array} \\
& \frac{(9,992,370,000)(156,598,021)}{3(19,984,740,000)-(9,992,370,000)} \\
& \mathrm{b}=\frac{7,476,085,048,919,810}{-140,021,520,000} \\
& \mathrm{~b}= 187,044.8414
\end{aligned}
$$

Hasil yang diperoleh untuk menghitung Regresi Linear Sederhana :

$Y=-8,734,790,000,000,000,000+187,044.8414 X$

Berdasarkan persamaan tersebut maka dapat di jelaskan koefisien variabel bertanda positif artinya antara penyaluran kredit terhadap sisa hasil usaha hubungannya negatif, dimana apabila penyaluran kredit kurang akan menurunkan sisa hasil usahanya, begitu pula sebaliknya apabila penyaluran kredit meningkat, maka sisa hasil usaha juga mengalami peningkatan. 


\section{SANG PENCERAH}

Volume 2, Nomor 1, Februari 2016, Hlm. 17-22

Azaluddin: Pengaruh Penyaluran Kredit Terhadap Sisa ...

\section{Simpulan}

Simpulan penelitian ini adalah penyaluran kredit pada Koperasi Simpan Pinjam Sejahterah Kota Baubau selalu meningkat, tetapi perkembangan peningkatannya dari tahun ke tahun cenderung Menurun. Hal ini di akibatkan karena adanya anggota yang keluar karena pindah kerja, pensiun, atau berhenti atas kehendaknya sendiri dan disebabkan pula oleh bertambah serta berkurangnya setoran simpanan wajib dan simpanan pokok dari para anggota, bertambah atau berkurangnya dana cadangan yang ada pada koperasi; Sisa hasil usaha pada Koperasi Simpan Pinjam Sejahterah Kota Baubau dari tahun 2011 sampai dengan tahun 2013 juga cenderung fluktuatif. Hal ini di sebabkan oleh semakin besarnya modal sendiri yang mampu dihimpun oleh koperasi, bertambah atau berkurangnya pendapatan yang di peroleh baik dari bunga pinjaman dan deviden atas jasa simpan pinjam dan investasi yang di lakukan oleh koperasi, serta bertambah atau berkurangnya biaya-biaya yang di keluarkan dari unit-unit usaha pada koperasi.

\section{Daftar Pustaka}

Anonim. 2007. Standar Akuntansi Keuangan. Salemba Empat: Jakarta.

\footnotetext{
---------. 2012. Laporan Pertanggung Jawaban Pengurus Koperasi Simpan Pinjam Sejahtera. Baubau
}

Anoraga, Pandji. 2007. Otonomi dan Manajemen Bisnis. Jakarta: Rineka Cipta.

2007. Manajemen Koperasi Teori dan Praktik. Jakarta: Pustaka Jaya.

IAI. 2007. Keuangan (PSAK). Medan: USU Sumatera.
Kartasapoetra, G., dkk. 2007. Koperasi Indonesia. Jakarta: Rineka Cipta

Kasmir. 2006. Kewirausahaan. Jakarta: PT Raja Grafindo Persada.

- 2010. Dasar-Dasar Perbankan. Jakarta: PT Raja Grafindo Persada.

--------. 2012. Bank dan Lembaga Keuangan Lainyna. Jakarta: PT Raja Grafindo Persada.

Sitio, Tamba. 2002. Koperasi Teori dan Praktik. Jakarta: Erlangga.

Subandi. 2008. Ekonomi Koperasi Teori dan Praktik. Bandung: Alfabeta.

Sudjana, Nengah. 1991. Pengaruh Penyaluran Kredit Terdahap Pendapatan Usaha Kecil. Skripsi Universitas Brawijaya Malang. Malang.

Sugiyono. 2009. Metode Penelitian Bisnis. Bandung: Alfabeta.

Supranto, J. 1998. Statistik Teori dan Aplikasi Jilid 2. Jakarta: PT Gelora Aksara Pratama.

Teguh, Pudjo. 2011. Pemberian Kredit / Pinjaman. Yogjakarta: BPFE.

Tunggal, Amin Widjaja. 1995. Akuntansi Untuk Koperasi. Jakarta: Rineka Cipta.

Widianti, Ninik dan Sunindhia. 2003. Dinamika Koperasi. Jakarta: Rineka Cipta. 